GEOLOGICAL SURVEY CIRCULAR 600

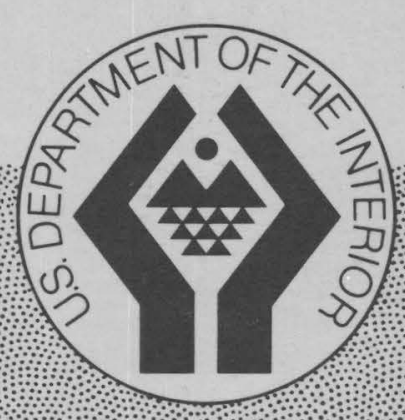

Geochemical Evidence for

Possible Concealed Mineral Deposits

Near the Monticello Box

Northern Sierra Cuchillo

Socorro County, New Mexico 

Geochemical Evidence for Possible Concealed Mineral Deposits Near the Monticello Box Northern Sierra Cuchillo Socorro County, New Mexico By Wallace R. Griffitts and Henry V. Alminas

GEOLOGICAL SURVEY CIRCULAR 600

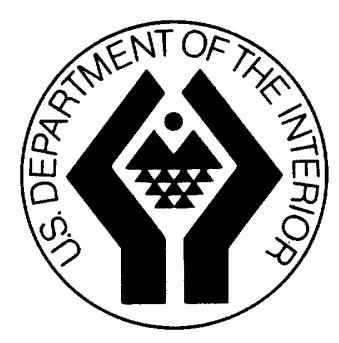


United States Department of the Interior STEWART L. UDALL, Secretary

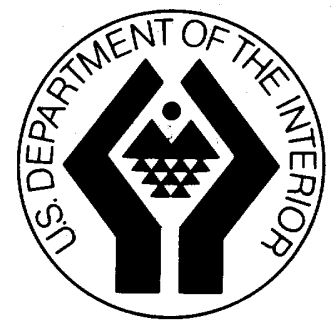

\section{Geological Survey}

William T. Pecora, Director

\section{$x$}




\section{CONTENTS}

\begin{abstract}
Introduction

Regional geology

Geology of the Monticello Box area

General geology
\end{abstract}
Page Geology of the Monticello Box area-Continued Rock alteration and mineralization Geochemical investigations
Summary
2 References cited

\section{ILLUSTRATIONS}

FIGURE 1. Index map showing location of the area sampled and of precious-metal districts in southwestern New Mexico

Page

2. Topographic map showing Monticello Box area and sample localities

3. Geochemical profile showing comparison of lead contents of nonmagnetic concentrates and of minus 80-mesh fractions of alluvial samples taken from the first canyon south of Montoya Butte

4. Map showing collection localities for samples containing anomalous amounts of copper, zinc, molybdenum, lead, or barium and locations of thick calcite veins and of areas of altered rocks

5-8. Maps showing content of lead, molybdenum, zinc, and copper in nonmagnetic concentrates from alluvium at sampled localities, Monticello Box area:

5. Lead

6. Molybdenum

7. Zinc

8. Copper 


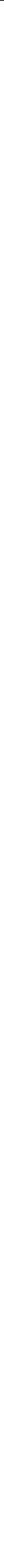




\title{
GEOCHEMICAL EVIDENCE FOR POSSIBLE CONCEALED MINERAL DEPOSITS NEAR THE MONTICELLO BOX, NORTHERN SIERRA CUCHILLO, SOCORRO COUNTY, NEW MEXICO
}

\author{
By Wallace R. Griffitts and Henry V. Alminas
}

\begin{abstract}
Ores of gold and silver have long been known in Tertiary volcanic rocks and in Paleozoic limestone along a north-trending belt near the east edge of the volcanic field in southwestern New Mexico. Several areas of altered volcanic rock in the belt may be underlain by concealed mineral deposits in the sedimentary rocks. Recent geochemical surveys in altered areas showed that mineralization is associated with the alteration at the north end of the Sierra Cuchillo, near the Monticello Box.

The volcanic rocks in the Monticello Box area consist of latite and andesite and overlying rhyolitic flows and tuffs. The volcanic rocks are cut by many faults, most having small displacement, and they have locally been subjected to argillic or chloritic alteration. Large calcite veins, containing little metal, cut the volcanic rocks. Below the lowest latite may be Paleozoic rocks, which are not exposed in that area. The volcanic rocks thus may be virtually barren caprocks that were altered by solutions escaping from the ore deposits in the underlying limestone.

Nonmagnetic parts of concentrates panned from arroyo sediments southeast of Monticello Box contain as much as 2 percent lead, at least 0.2 percent each of molybdenum, zinc, and copper, and anomalous amounts of barium and silver. Tellurium was found in the part of the original sample that passed through an 80-mesh sieve, but this material was otherwise much less useful than the concentrates in outlining the anomalies. The sources of the metals in the sediments are areas of chloritized rock, the fillings of small fissures, and perhaps some northeast-trending mineralized fault zones.
\end{abstract}

\section{INTRODUCTION}

Deposits of precious metals have long been known in many places in the volcanic rocks and in the underlying sedimentary rocks in a north- trending belt near the east edge of the volcanic field in southwestern New Mexico. Nevertheless, widespread areas of altered rocks appear to have been little prospected, as they contain few or no prospect pits or other evidence of investigation. Thus, there remains a good chance for discovery of either concealed or exposed ore deposits in previously neglected areas. We have carried out geochemical surveys around areas of altered rock in and near the Sierra $\mathrm{Cu}$ chillo, especially near the north end of the range, 36 miles northwest of Truth or Consequences, N. Mex. (fig. 1). The work was done as part of the Heavy Metals program of the U.S. Geological Survey.

In our fieldwork we benefited from the courtesy and efforts of many people. Sam and Jim Cox, Victor and Frank Sullivan, and Eunice T. Travis allowed us on their ranches. M. Howard Milligan, a consulting geologist from Albuquerque, N. Mex., and lessee of mineral rights under a part of the area, helped obtain access to it. Patrick D. Hilliard completed geologic mapping in 1967 of a 51/2-square-mile area near the Monticello Box at the north end of the Sierra Cuchillo. The area of his map includes much of the northernmost area which we sampled and which contains the strongest geochemical anomaly found in the range, the one which is the main subject of this report.

\section{REGIONAL GEOLOGY}

The volcanic field, which is about 200 miles across, contains various mafic to silicic extru- 
sive and dike rocks of Tertiary age and, in its northern part, olivine basalts of Quaternary age. The volcanic rocks have not yet been studied or mapped in detail, but fortunately for present purposes we need only to distinguish between the Tertiary rocks, most of which predate mineralization, and the Quaternary basalts, which postdate all the known mineralization of the region. The late basalts apparently are not present in or near the Sierra Cuchillo.

The volcanic rocks and the underlying sedimentary rocks are cut by many north-striking normal faults to form a series of eastwardtilted fault blocks in the Sierra Cuchillo. These faults, largely unmapped in the volcanic rocks, and the rather high relief of the prevolcanism unconformity prevent accurate estimation of the total thickness of volcanic rocks at most places.

This region was selected for study because of three geologic features that are found near the eastern edge of the volcanic field. The most important of these, shown in figure 1, is a broad north-trending belt of precious-metals districts, which occur in part in windows through the volcanic rocks and in part in the volcanic rocks themselves. The ore metals of this belt differ markedly from those in a belt of nonsulfide deposits of manganese, barium, cerium, and fluorite to the east, across the Rio Grande. Second, metal deposits containing gold and (or) silver are reported from Paleozoic rocks in nearly all areas in which these rocks are exposed. Third, widespread but localized hydrothermal activity is indicated by hydrothermal alteration of the volcanic rocks. It seems plausible that this hydrothermal activity was in places accompanied by metallization and also that any resulting ore deposits would be similar in composition to those in other districts in the belt. The mineralization might well produce ore deposits in the sedimentary rocks with only traces of metal in overlying volcanic rocks that were altered by escaping, nearly spent solutions.

\section{GEOLOGY OF THE MONTICELLO BOX AREA}

\section{GENERAL GEOLOGY}

The Monticello Box area, as used here, is the area underlain by volcanic rocks that extends southeast for about 4 miles from the Monti- cello Box on Alamosa Creek (fig. 2). The area is bounded on the west by a gravel-filled basin and on the east and north by Alamosa Creek. Hilliard (1967) reported the following lithologic units (arranged in approximate order of increasing age): gravel, flow-banded rhyolite, massive rhyolite, rhyolite tuff, sedimentary rocks, andesite and latite flows, and latitic tuff and coarser pyroclastic rocks.

The andesite and latite flows are the most widespread volcanic unit in the area. They are commonly dark greenish gray, and both color and luster depend upon the degree of alteration. The unit rests upon about 600 feet of latitic tuff and pyroclastic rocks which are exposed along the east side of the area. These two units resemble the "andesitic breccia" and overlying "andesitic and latitic lavas and tuffs" which Jahns (1944) found at the base of the volcanic sequence at Iron Mountain, about 7 miles to the southwest. Therefore, sedimentary rocks may not be far below the latitic tuff along Alamosa Creek. The andesite and latite flows are overlain by rhyolite tuffs and flows. An increase southward in the amount and contortion of layered rhyolite suggests that a volcanic vent lies in that direction.

Hilliard found dikes of latite, porphyritic andesite, and basaltic andesite and of quartz latite equivalent to the rhyolite mapped by Jahns (1944) at Iron Mountain. One small plug of quartz monzonite is in the NW1/4 sec. 8.

Many faults and fractures, most having only small displacement, cut the volcanic rocks. Most faults trend northeast, some trend northwest, and a few trend in other directions. Displacement of at least 700 feet along one northeaststriking fault accounts for the constriction of the Alamosa valley at the Monticello Box. Many of the faults predate mineralization, inasmuch as they contain veinlets of quartz, fluorite, or calcite.

\section{ROCK ALTERATION AND MINERALIZATION}

The most conspicuous result of mineralization in this area is the thorough argillization of the volcanic rocks near the northwestern edge of the area sampled. The sides of a draw there consist of chalky-white, brown, or red masses of clay. Kaolinite is the most widespread product of alteration, and Hilliard (1967) also 
found alunite and montmorillonite. Eastward and southward the alteration decreases in intensity and changes in character. The rocks remain firm and coherent but are stained red or brown with iron oxides and contain chlorite, a general type of alteration that is extensive in sec. 5 and decreases eastward and southward. Epidote was seen along fractures in outcrops near the western boundary of sec. 5, in the northeastern corner of sec. 7 , and near the southern edge of secs. 16 and 17. All these localities are near the western or southern edges of the metal anomaly outlined in figure 2 . Less conspicuous epidote in the interior of the anomaly-perhaps in a disseminated state -is attested to by its presence in many panned concentrates, even where it was not seen in the field.

Only one metalliferous vein has been explored in this area, at the Taylor prospect in sec. 5 (fig. 4) where several tons of oxidized ore containing copper, lead, silver, and zinc are reported to have been recovered from a quartz vein that is a few hundred feet long and 5 feet in maximum width. Other veins of quartz and outcrops of lead-rich gossan which we examined in the area have not been disturbed. Fluorite and barite are widespread in the strongly and moderately argillized rock south of Monticello Box and can be panned from wash sediment in most places. Fluorite cubes were found in float in an area of moderately altered rock in sec. 8. The general pattern is one of widespread mineralization without evidence of a minable deposit at the surface.

Calcite forms veins 5-15 feet thick near the western edge of sec. 5 and near the middle of sec. 7 (fig. 4). In most veins the mineral grains do not exceed one-half inch in diameter, but a vein that crops out about one-half mile south of Allison well in sec. 7 is much coarser, having grains several inches across. These large calcite veins contain only traces of base metals and silver. East of the above-mentioned veins calcite is less conspicuous and forms thin veinlets, usually accompanied by quartz, that are a fraction of an inch to a few inches in thickness. The size and number of calcite veins increase at the southern edge of the anomaly, and calcite-quartz and calcite-chalcedony veins are conspicuous in the southernmost canyon sampled. Calcite and epidote are thus similar in distribution, both minerals occurring most conspicuously near the southern and western edges of the anomaly.

Calcite is, of course, a common component of hydrothermal veins, both metalliferous and barren. Hence, the many minor veins in the interior of the anomaly are perhaps of little significance. The massive veins along the western margin of the anomaly are different in texture and presumably in origin. They are in the most intensely mineralized parts of the area, between the intensely argillized rocks to the west and an area to the southeast that is particularly high in copper (fig. 4). The calcite may represent a waste product of mineralization of limestone below the volcanic rocks.

A deposit of an entirely different type, perhaps not related genetically to the base-metal mineralization, was found by M. Howard Milligan in 1961 about one-half mile south of Monticello Box. In this deposit, bertrandite (a hydrated beryllium silicate) has been introduced into faulted volcanic rocks. Beryllium was detected in substantial amounts in samples of alluvium derived from the area of Milligan's prospect but was not found elsewhere in the Monticello Box area.

\section{GEOCHEMICAL INVESTIGATIONS}

The objectives of the geochemical survey were to determine if there is evidence of metallization associated with the hydrothermally altered volcanic rocks and then, if such evidence was found, to determine the extent of the affected area. The most rapid and economical method appeared to be a moderately detailed sampling of the sediment from the canyons and arroyos, all of which are usually dry. A sample was taken at the mouth of each canyon at its junction with Alamosa Creek or with the draw in argillized rock south of Monticello Box. This reconnaissance was followed by the sampling of each tributary of each canyon that contained anomalous metal. As is evident in figure 2 , some tributaries are nearly a mile long and collect alluvial material from large areas, whereas others are no more than small depressions in the walls of the canyons.

Two samples were taken at each location. The first sample, consisting of about $1 \mathrm{lb}$ (pound) of 
sediment, was sieved to minus 80-mesh and analyzed by spectrographic and other methods.

The second sample, consisting of about 10 $\mathrm{lb}$ of sediment, was panned and the concentrate was cleaned with bromoform. Ilmenite and magnetite were removed and the remaining material was split with a Frantz Isodynamic Separator at a 1-ampere setting. Visual examination of the nonmagnetic fraction prior to spectrographic analysis showed its prominent components to be limonite, fluorite, barite, zircon, rutile, sphene, and several unidentified lightcolored minerals. Wulfenite $\left(\mathrm{PbMoO}_{4}\right)$ and lead-bearing limonite are the only minerals we found that are rich in ore metals. Cerussite and molybdenum-bearing limonite were sought but not found.

Each portion of the samples was analyzed by semiquantitative s pectrogra phic methods (Ward and others, 1963). Supplementary determinations for gold, tellurium, mercury, antimony, and acid-soluble lead were made on selected samples.

These analyses were made by our colleagues Arnold Farley, Jr., Elwin Mosier, J. M. Nishi, John Watterson, Thelma Harms, R. L. Turner, E. P. Welsch, Elizabeth Martinez, Jerry Motooka, K. C. Watts, R. F. Hansen, M. S. Richard, W. L. Campbell, R. L. Miller, and T. A. Roemer.

The most informative determinations were those made by spectrographic analysis and by visual examination of the nonmagnetic concentrates. Tellurium determinations made on minus 80-mesh sample material effectively distinguished mineralized from unmineralized terranes, but other determinations on the same material were of much less value. The anomaly at Monticello Box might even have escaped notice if the only data available were of metal contents of minus 80-mesh material. The marked enhancement of contrast between areas with anomalous and background metal contents which we obtained by analyzing concentrates is illustrated in figure 3 .

Figure 4, a general compilation of available geochemical data on copper, zinc, molybdenum, lead, and barium, shows that the anomaly as a whole is not delimited by a single element. In most places where one of the five elements is present in anomalous amounts, at least one other element also occurs in anomalous amounts.

The background values for copper, zinc, molybdenum, lead, and barium used in compiling figure 4 were set high enough to minimize the effect of erratic variations that result from the widely varied lithology of the volcanic rocks. Each lithologic type naturally has its own local background value for each metal and we have, in effect, taken the highest of these local background values as the area background. Less conservative-lower-background values can be determined from figures 5 through 8 if a more complete distribution pattern is desired.

A comparison of the maps for each element, figures 5 through 8 , shows that anomalous copper values extend farther north than south of the main concentrations in the northern parts of secs. 8 and 9, that anomalous zinc and lead values extend farther south than north, and that molybdenum is somewhat less widely dispersed than lead and copper. The apparent immobility of molybdenum and the association of this metal with lead result at least partly from its presence in the soils as molybdate at a time when cations which form insoluble molybdates are also present.

The high metal values in alluvium are not closely related spatially to faults, although a few northeast-trending faults have been found in drainage basins containing metal-rich alluvium. Slightly to moderately altered rock seems more consistently to yield metalliferous debris than do faults of any trend.

Tellurium was found in many samples in the northwestern part of the anomaly, generally in amounts of tenths of parts per million. Silver was found in many lead-rich samples. Gold, on the other hand, was detected in only a few samples and its concentration was less than $0.02 \mathrm{ppm}$ (part per million) in most samples. Acid-soluble lead content of concentrates of minus 80-mesh material varies sympathetically in a general way with molybdenum and thus provides a rough measure of the molybdenum content. The other nonspectrographic determinations were less useful. Antimony was not detected in any sample; mercury was found only in very low concentrations, and the range in values was too slight to be useful. Visual examinations of heavy-mineral concentrates can 
be used to guide sampling and to help interpret or explain the geochemical data.

\section{SUMMARY}

Anomalous amounts of lead, zinc, copper, molybdenum, and barium have been found in altered volcanic rocks in the Monticello Box area. The geochemical anomaly combined with other regional and local geologic features suggests that concealed mineral deposits may be present in underlying Paleozoic carbonate rocks. The regional features of most significance are the presence of gold or silver in most known deposits in a broad belt that encompasses the Monticello Box area and the very widespread distribution of ore in limestones of Paleozoic age - ore has been found in most places where the limestones are exposed in windows through the volcanic rocks. Calcite was removed during replacement of the limestone by ore and gangue minerals. Presumably it was transported upward, through the volcanic rocks, by the oreforming solutions after they had been depleted of most of the metal ions. The volcanic rocks undoubtedly were hydrated during the process.

On a local scale we found several features that correspond to those seen or inferred in neighboring districts. The volcanic rocks are extensively and locally intensely altered; ore metals are in minor fractures and dispersed in altered rock. Thick calcite veins in the most strongly mineralized part of the area suggest replacement in the underlying limestones. We infer that the total thickness of the volcanic rocks may be only a few hundred feet. The weak lateral zoning of metals at the surface could then be explained best as a reflection of zoning in the underlying formations.

Neither the thickness of the volcanic rocks nor the exact distribution and nature of mineralization in the underlying sedimentary rocks could be determined from surface studies, and further investigation of these subjects and of the potential for concealed ore bodies should include geophysical studies and exploratory drilling.

\section{REFERENCES CITED}

Hilliard, P. D., 1967, General geology and beryllium mineralization near Apache Warm Springs, Socorro County, New Mexico: Socorro, New Mexico Inst. Mining and Technology, M.S. thesis, 58 p.

Jahns, R. H., 1944, Beryllium and tungsten deposits of the Iron Mountain District, Sierra and Socorro Counties, New Mexico: U.S. Geol. Survey Bull. 945-C, p. 45-79.

Ward, F. N., Lakin, H. W., Canney, F. C., and others, 1963. Analytical methods used in geochemical exploration by the U.S. Geological Survey: U.S. Geol. Survey Bull. 1152, $100 \mathrm{p}$. 


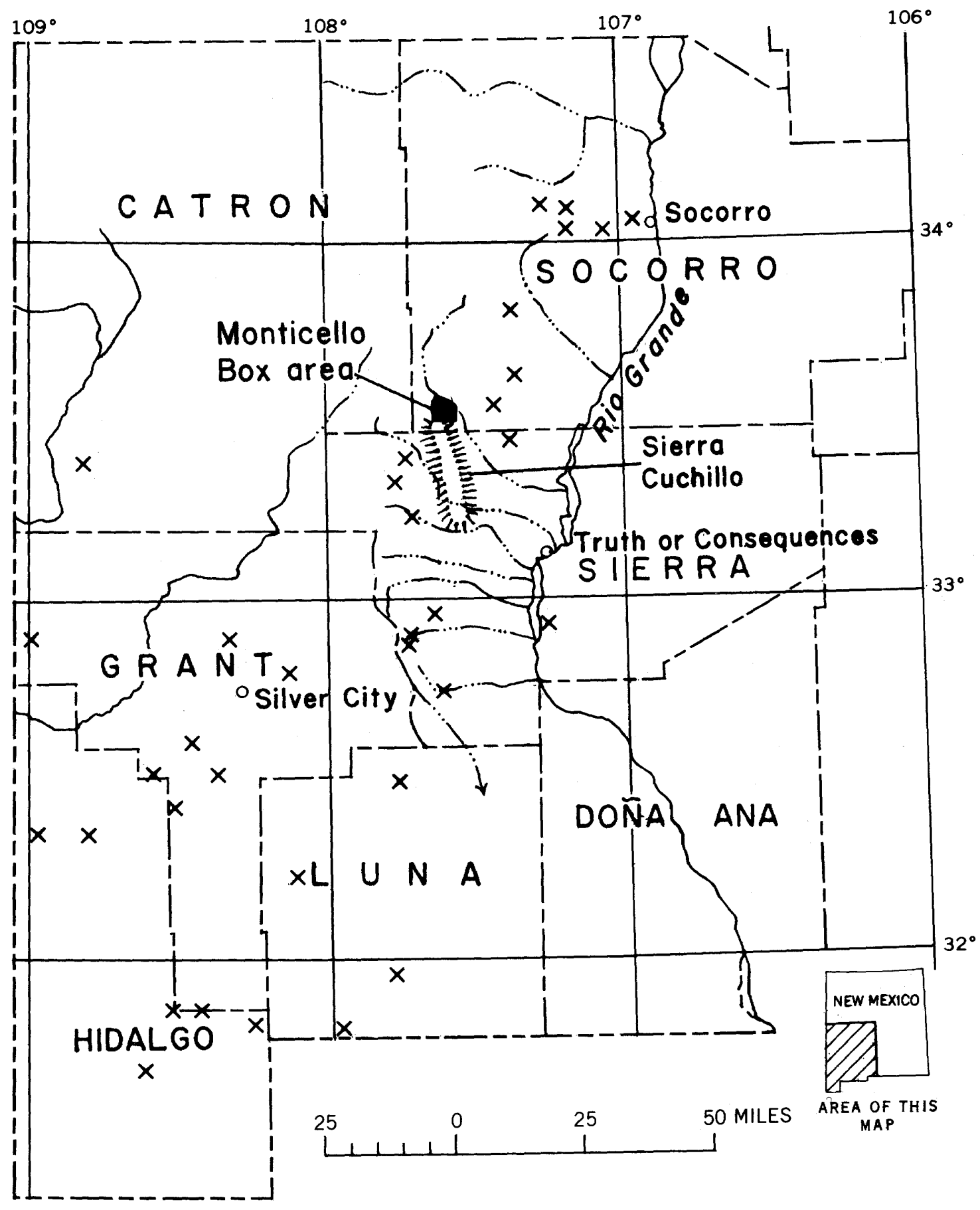

FIGURE 1.-Index map showing location of the area sampled and of precious-metal districts $(X)$ in southwestern New Mexico. 

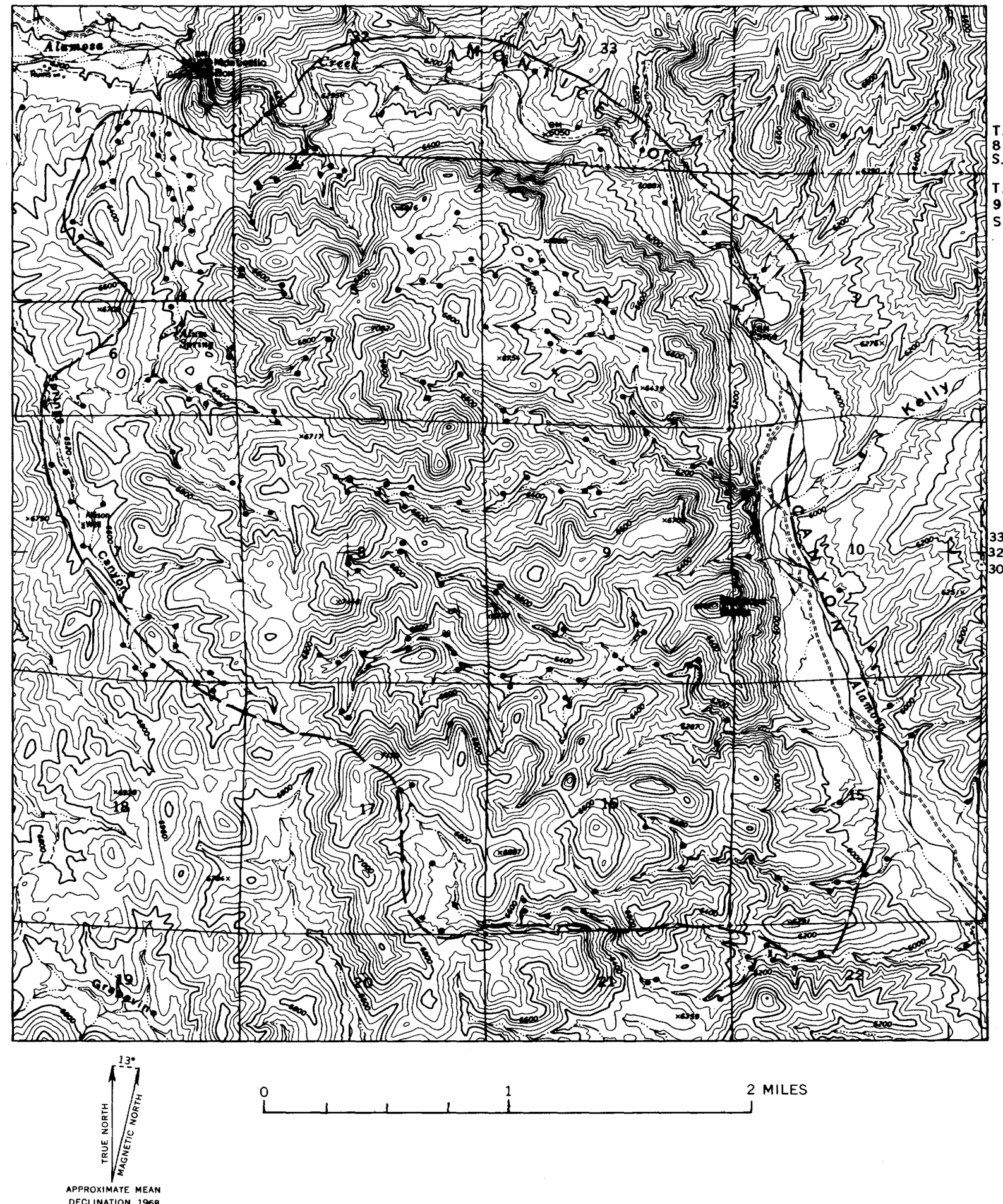

L

2 MILES

DECLINATION, 1968

Figure 2.-Map showing Monticello Box area and sample localities. Heavy dashed line is approximate limit of geochemical anomaly. Base from U.S. Geological Survey map of Montoya Butte quadrangle, 1964. 

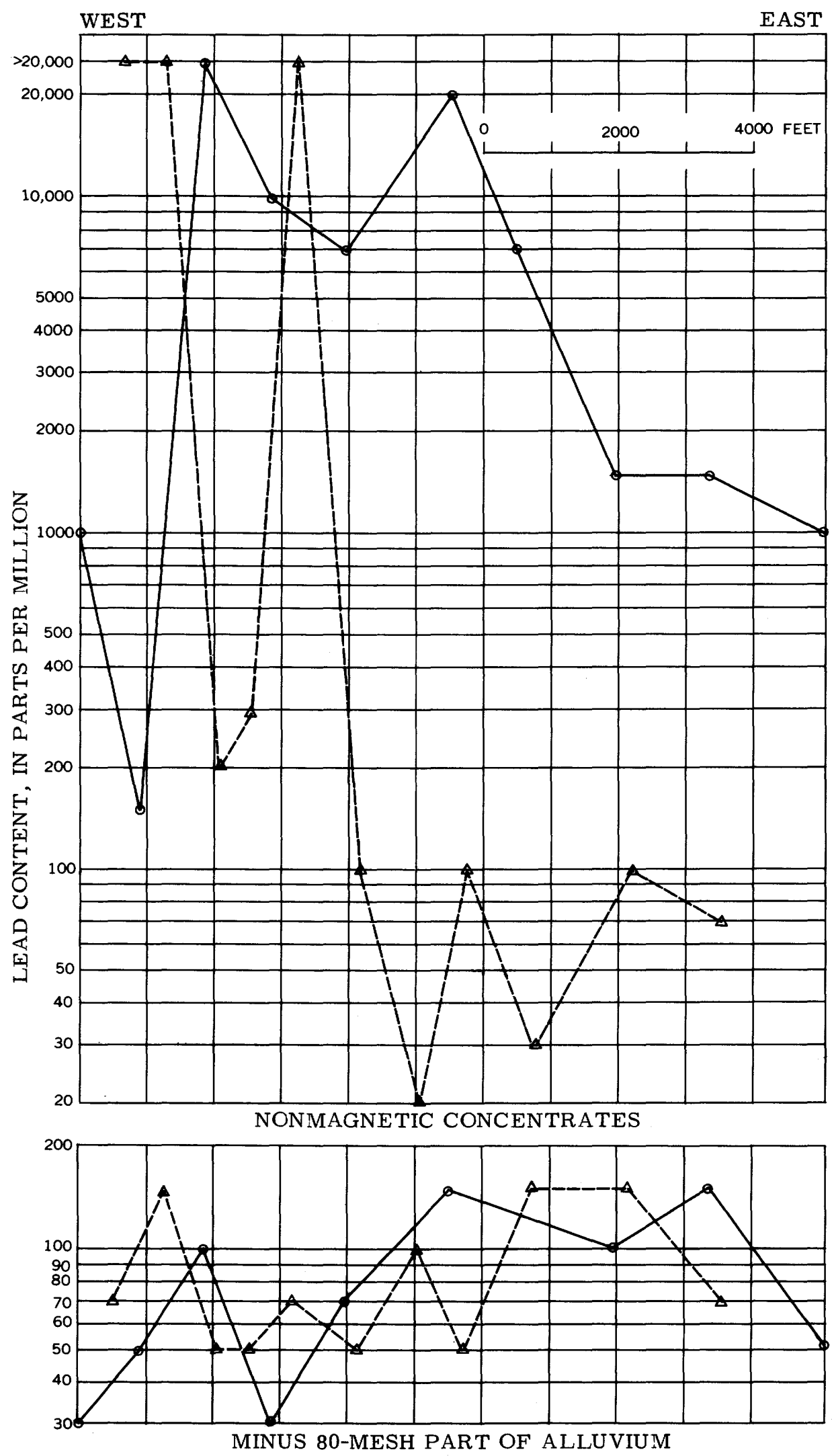

Figure 3-Comparison of lead contents of nonmagnetic concentrates and of minus 80-mesh fractions of alluvial samples taken from the first canyon south of Montoya Butte. Solid line connects values for samples taken from the main canyon. Dashed line connects values for samples taken from tributaries to the main canyon. 


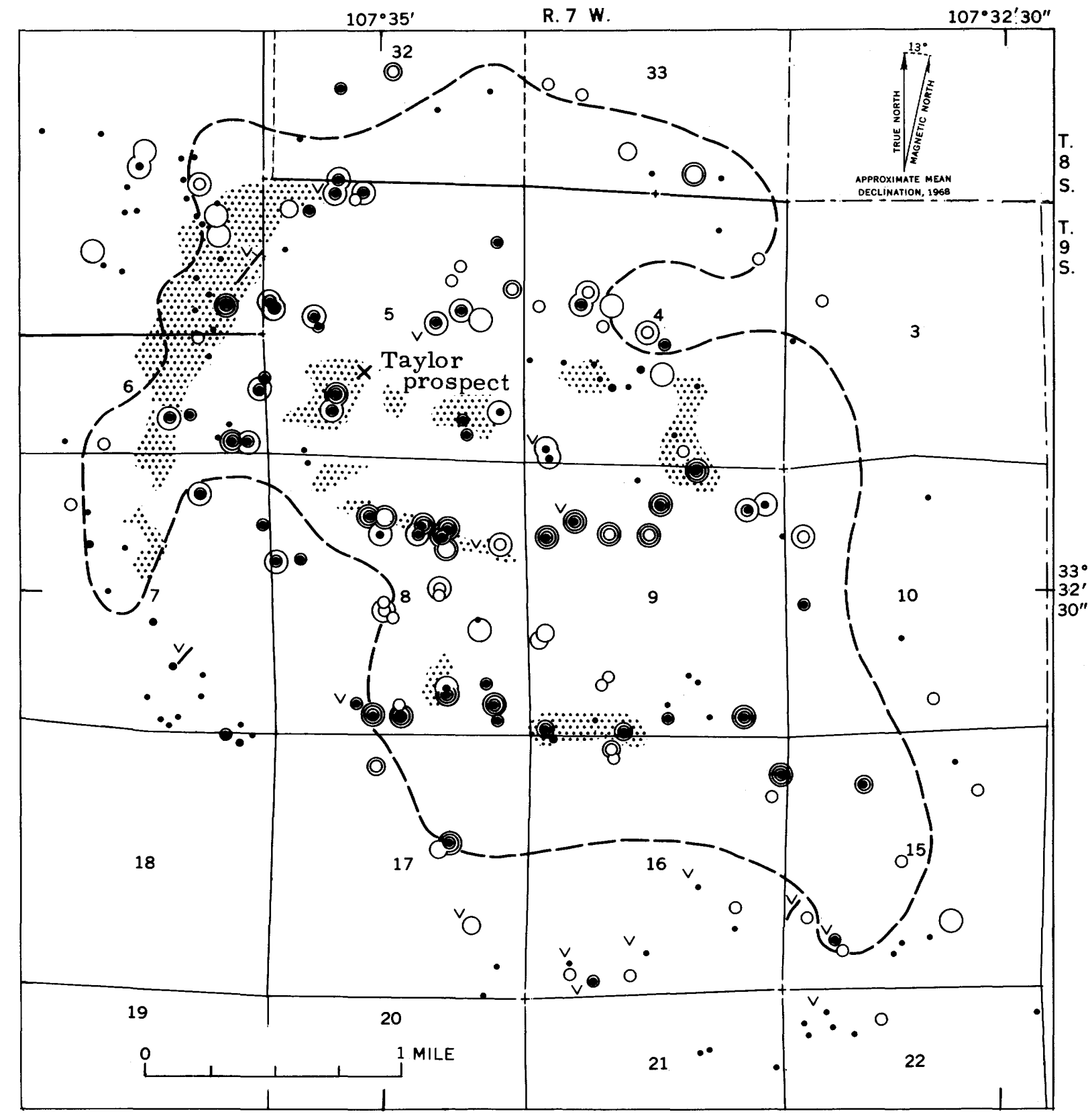

O

At least 100 ppm copper

O

At least 200 ppm zinc

O

At least 5 ppm molybdenum

At least 200 ppm lead

No anomalous metal by

Thick calcite vein

Line shows strike, where known

Boundary of area in which most samples contain at least 5000 ppm barium

習

Altered rocks

In part from Hilliard (1967)

Figure 4.-Collection localities for samples containing anomalous amounts of copper, zinc, molybdenum, lead, or barium and locations of thick calcite veins and of areas of altered rocks. All metal values were determined on nonmagnetic heavy concentrates. 


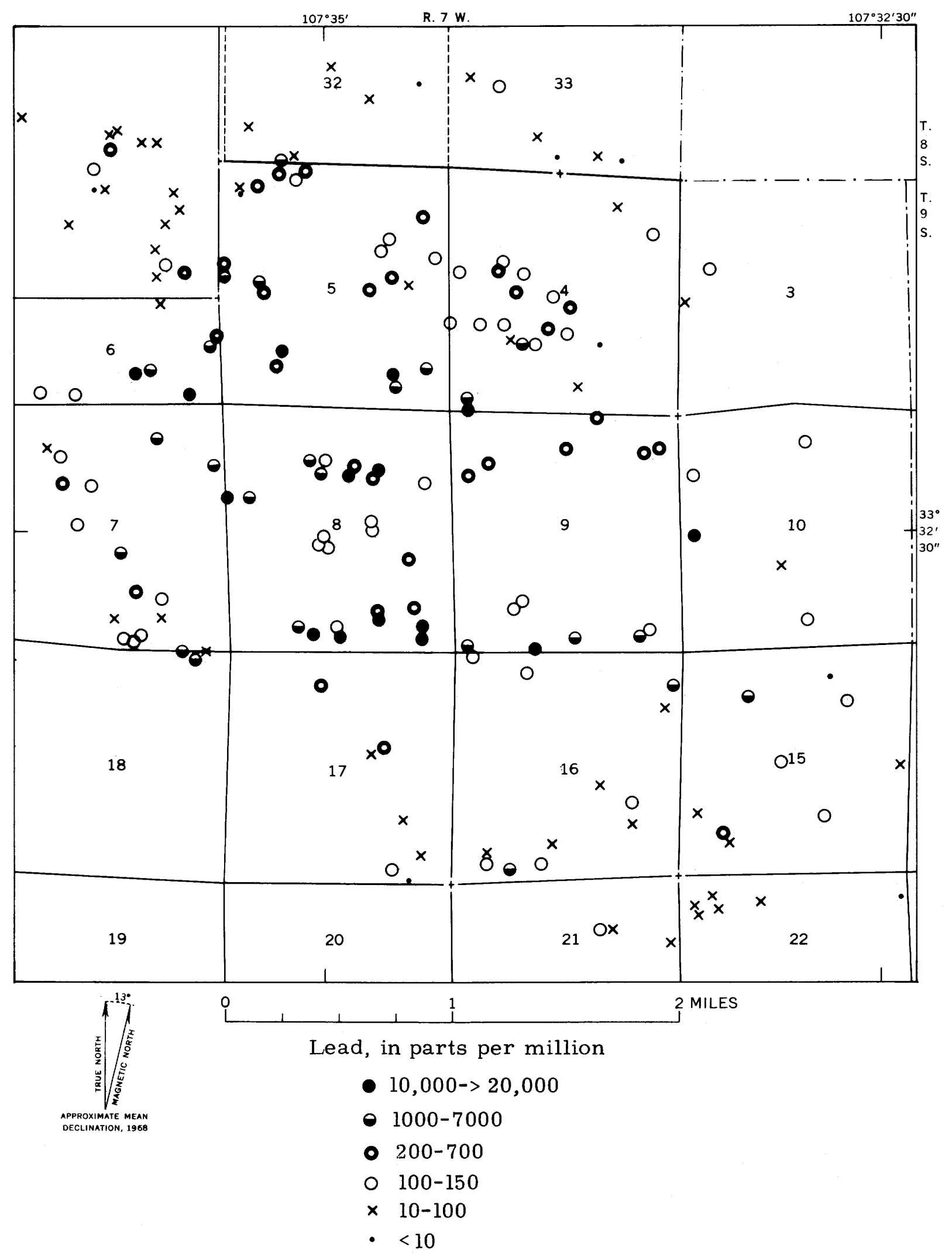

FIGURE 5.-Lead content of nonmagnetic concentrates from alluvium, Monticello Box area. 


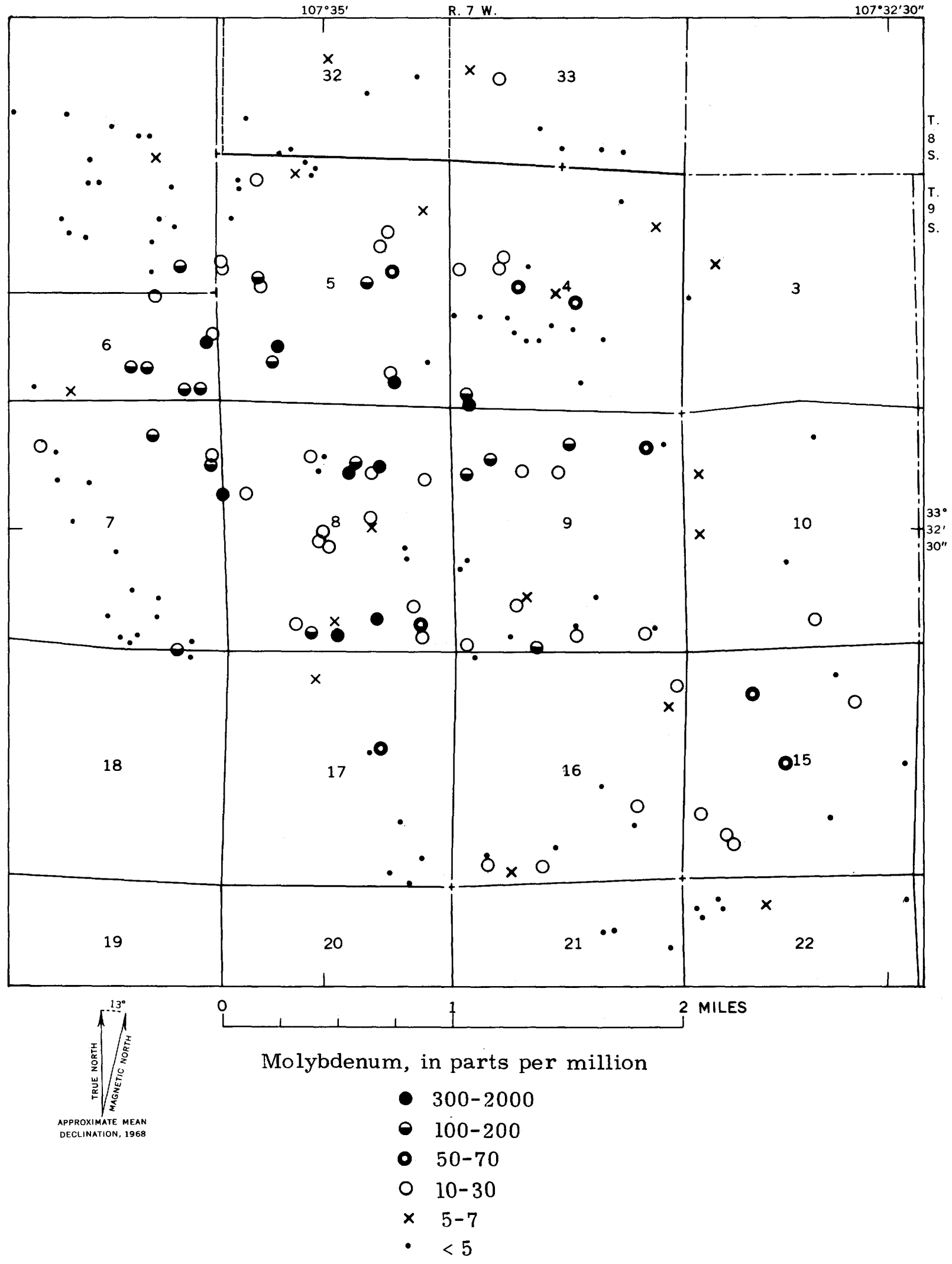

FigURE 6.-Molybdenum content of nonmagnetic concentrates from alluvium, Monticello Box area. 


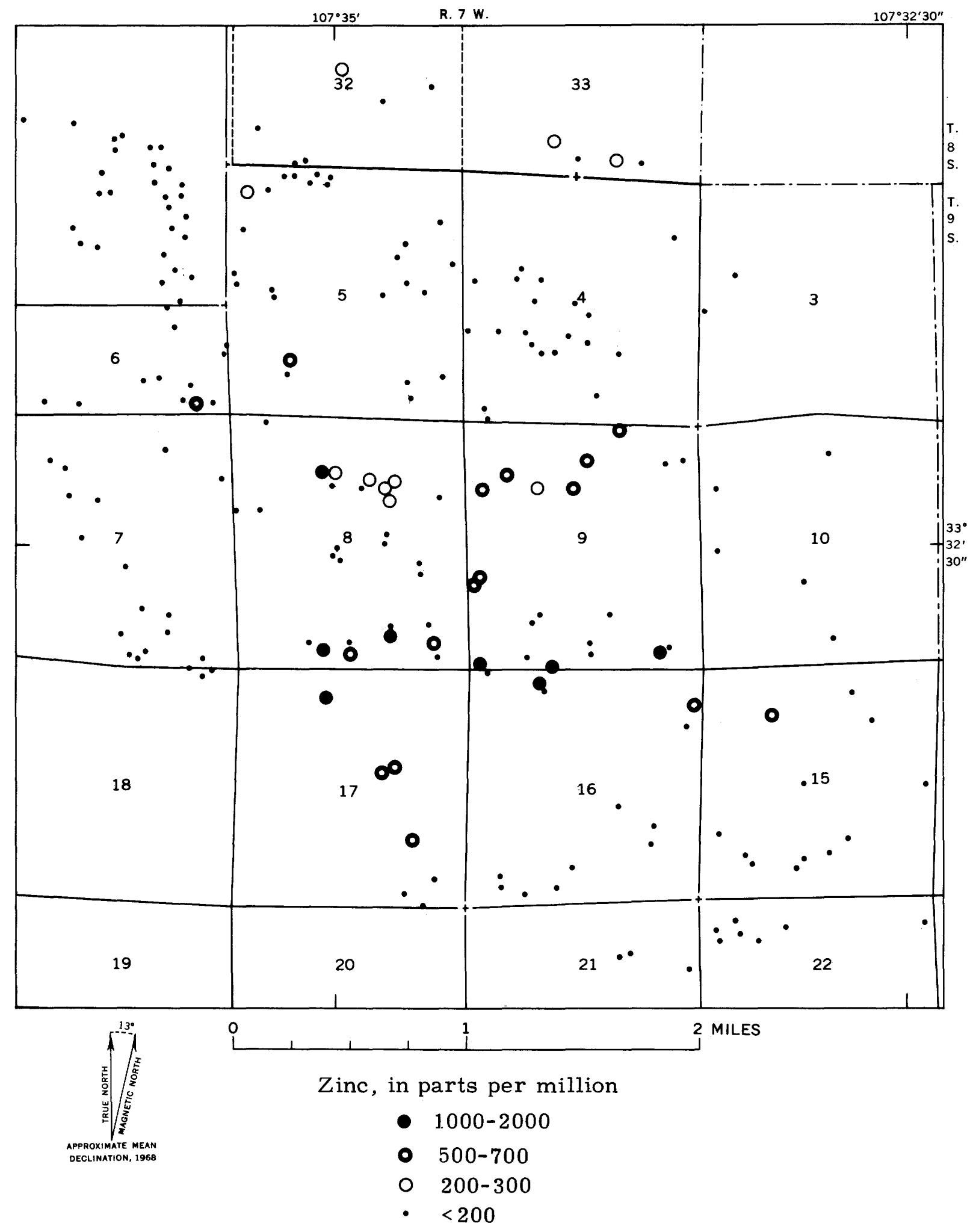

Figure 7.-Zinc content of nonmagnetic concentrates from alluvium, Monticello Box area. 


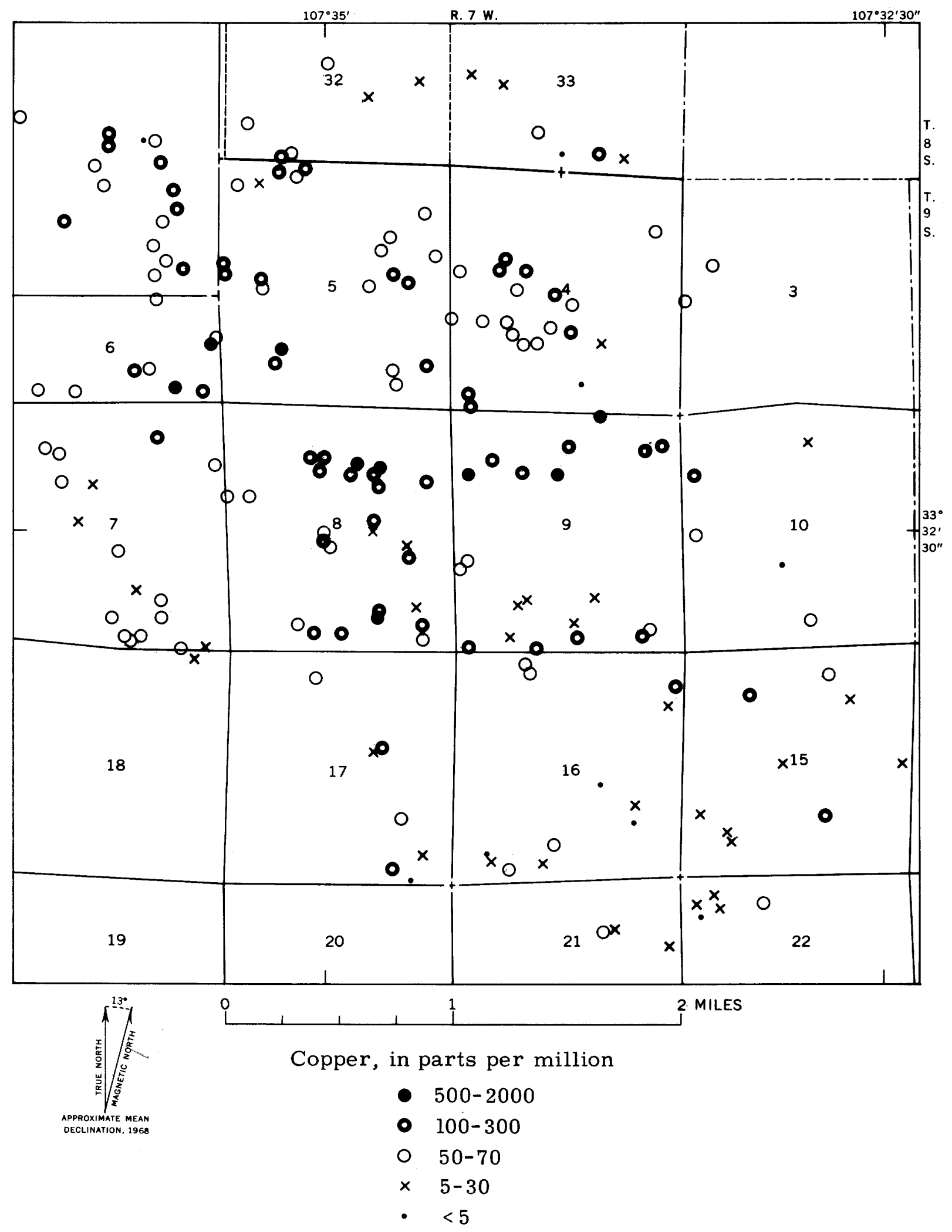

FigURE 8.-Copper content of nonmagnetic concentrates from alluvium, Monticello Box area. 


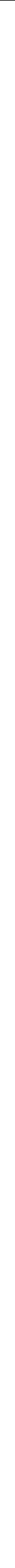

